2. Кашкадамова Н. Б. Історія фортеп'янного мистецтва XIX сторіччя : підручник. Тернопіль, 2006. 608 с.

3. Клин В. Українська радянська фортепіанна музика. Київ, 1980.316 с.

4. Корній Л. П. Історія української музики. Частина третя. (XIX ст.) : підручник. Київ - Нью-Йорк, 2001. 479 с.

5. Корній Л., Сюта Б. Українська музична культура. Погляд крізь віки. Київ, 2014. 592 с.

6. Фрайт О. Фортепіанні альбоми та цикли українських композиторів для дітей: історія і сучасність: навчально-методичний посібник. Дрогобич. 100 с.

7. Шреєр-Ткаченко О. Л. Історія української музики. Частина перша : Розвиток української музичної культури від найдавніших часів до середини XIX століття. Київ, 1980. 198 с.

\section{REFERENCES}

1. Bulat,T. P. (1989). Obrobky ukrainskykh pisen dlia holosu v suprovodi fortepiano [Processing of Ukrainian songs for voice accompanied by piano]. History of Ukrainian music in six volumes. Kyiv, Vol. 1, pp. 38-76. [in Ukrainian].
2. Kashkadamova, N. B. (2006). Istoriia fortepiannoho mystetstva XIX storichchia : pidruchnyk. [The history of piano art. XIX century: textbook]. Ternopil, 608 p. [in Ukrainian].

3. Klyn, V. (1980). Ukrainska radianska fortepianna muzyka [Ukrainian Soviet Piano Music]. Kyiv, 316 p. [in Ukrainian].

4. Kornii L. P. (2001). Istoriia ukrainskoi muzyky. Chastyna tretia. (XIX st.) : pidruchnyk. [The history of Ukrainian music. p. 3 (XIX century): textbook]. Kyiv Niu-York, 480 p. [in Ukrainian].

5. Kornii, L. \& Siuta, B. (2014). Ukrainska muzyczna kultura. Pohliad kriz viky [Ukrainian music culture. A look throught heages]. Kyiv, 592 p. [in Ukrainian].

6. Frait, O. (2013). Fortepianni albomy ta tsykly ukrainskykh kompozytoriv dlia ditei: istoriia i suchasnist [Piano albums and cycles of Ukrainian composers for children: history and modern times]. Drohobych, $100 \mathrm{p}$. [in Ukrainian].

7. Shreier-Tkachenko, O. L. (1980). Istoriia ukrainskoi muzyky. Chastyna persha [The history of Ukrainian music]. Kyiv, 198 p. [in Ukrainian].

Стаття надійшла до редакції 23.05.2019

УДК 373.3/.5].014(410+477)

DOI:

Галина Лотфі Гаруді, викладач кафедри іноземної мови Національного університету “Львівська політехніка"

\title{
ПОЛІТИКА УПРАВЛІННЯ ОСВІТОЮ УКРАЇНИ ТА ВЕЛИКОЇ БРИТАНІЇ
}

У статті висвітлено головні напрямки реформи у галузі загальної середньоі освіти України та Великоі Британії. Зокрема, йдеться про перегляд національного курикулуму, удосконалення освітної системи відповідно до світових стандартів. Показано зміни в освіті та ї̈ реформуванні. Виокремлено механізми впровадження основних європейських норм і стандартів у формуванні сучасного вектора розвитку національної освіти та виявлено завдання свідомо регульованого удосконалення шкільної освіти. Проаналізовано курс програм освітніх систем. Доведено ефективність впровадження нововедень, а саме “модуль” як навчальний пакет.

Ключові слова: реформа; навчальний курикулум; освітя система; модульне навчання; стандарти досягнень; загальне свідочттво про середню освіту.

Лim. 12.

Halyna Lotfi Ghahrodi, Lecturer of the Foreign Languages Department National University "Lviv Polytechnic"

\section{EDUCATIONAL MANAGEMENT POLICY OF UKRAINE AND GREAT BRITAIN}

This article highlights the main direct reforms of secondary education in Ukraine and Great Britain. In particular, it is about the revision of the national curriculum, improvement of the educational system in accordance with the world's standards. Paper shows changes in education and its reforms. The mechanisms of implementation of the basic European norms and standards in the formation of the modern vector of development of national education are identified and the problem of knowingly regulated improvement of school education is revealed. The course of programs of educational systems is analyzed here. Education is the only sphere where a society adjusts its needs. English educational traditions are characterized by the persistence of traditions, differing in their organization, content and prospects. The British government is not willing to change in their educational system, although it believes that they should be up-to-date, should fulfill the function of spiritual formation of both man and mankind in general, not to make a breakthrough in achieving spiritual and intellectual progress of educational policy. The state of affairs in the school education system of Great Britain in recent years is clear evidence of great achievements in this area. The equilibrium of the quantity and quality of education is dictated by the new, diverse, growing 
requirements of the world. The traditions of the rapid development of society, the rapid increase of international mobility, and the peculiarities of the future student's training determine the flexible response to changes in the structure of the system of education and public life. Modern trends have led to the unification of curricula and programs at the level of educational content. The article contains a number of helpful tips which are studied, analyzed and are being implemented as a piece of practical advice on the subject. However, the changes invent new approaches, and this leads to a search for new possible ways that may influence the education system in a better way.

Keywords: reform; cirriculum; education system; modular training; standards of achievment; general secondary education certificate.

A

наліз останніх досліджень та публікаціи. Впродовж значного проміжку часу реформування британськоі шкільноі освіти займалися такі науковці, як Клаид Чіті, Дерек Гіллард, Девід Колбі, Роберт Філліпс та ін. Широкии спектр питань у галузі шкільньоі освіти Великої Британії викликає науковий інтересів й українських дослідників, таких як: Н.М. Лавриченко, О.І. Локшиної, О.О. Першукової, О.К. Мілютіної, А.А. Сбруєвого.

Мета статті. Сьогодні Велика Британія, як і Україна, перебуває устані реформ, що стосуються усіх ланок системи освіти. Метою статті є висвітлення політики сучасного британського уряду щодо реформування шкільної освіти. Особливо вирішальною проблемою змісту освіти в умовах глобалізаційних процесів $є$ розбудова суспільних знань. Цілком зрозуміло, що не реально покращити якість освіти без реформування іiі змісту.

Виклад основного матеріалу. Модернізація вітчизняної освіти почалася ще 390 -х років XX сторіччя. Із прийняттям Закону України "Про освіту” (2017р.) [2], розвиток інноваційних підходів до освіти став однією з умов виходу країни на належний європейський рівень Розпочалася не лише державно-політична а й соціально-освітня зміна устрою держави. 5 вересня 2017 року Верховна Рада України ухвалила новий закон "Про освіту”. Цей закон є рамковим законом “Про освіту”, який був прийнятий у 1991 році. Цим законом уряд запроваджує дванадцятирічне компетентнісне навчання, діти, які пішли у перший клас 3 вересня 2018 року, будуть навчатися 12 років.

Закон передбачає перехід до компетентнісного навчання, де знання використовують на практиці. Школа розділена на: початкову (1 - 4 класи); базову (5 - 9 класи); профільну (10 - 12 класи). Старша школа профільного навчання матиме ліцеї академічного та професійного спрямування. Закон надає більше автономії школам; директора школи будуть обирати на конкурсній основі, терміном на 6 років. Закон скасовує атестацію шкіл та інспекцій управління освіти. Відтепер Державна служба якості освіти, як нова модель контролю проводитиме інституційний аудит шкіл. Раз в 10 років буде здійснений такий плановий захід державного нагляду. Його мета - надати школі рекомендацій стосовно покращення навчального процесу. Закон передбачає те, що вчитель самостійно вибирає, де саме проходить підвищення кваліфікації протягом 5 років і не менше 150 годин. Цей закон дає дозвіл вчителям працювати за розробленими освітніми програмами чи використовувати типову програму, яку дає МОН. Прозорість шкільних фінансів, які школа мусить публікувати на своєму сайті, щоб батьки, вчителі та усі зацікавлені особи змогли простежити правильність використання коштів теж передбачене законом. 5 березня 2018 року МОН винесло на обговорення проект наказу “Про затвердження Порядку зарахування, відрахування та переведення учнів до державних та комунальних закладів освіти для здобуття повної загальної середньої освіти", стосується учнів шкіл, гімназій та ліцеїв.

“Для зарахування дитини до 1 класу один 3 батьків дитини особисто має подати до закладу освіти заяву та інші документи $[\ldots]$ не пізніше 3 травня. Заява подається до закладу освіти, за яким закріплена територія обслуговування, на якій проживає ця дитина. Крім того, один з батьків дитини за його вибором може подати заяви до інших закладів освіти для зарахування на вільні місця" [2], - зазначається у документі.

У Великій Британії чотирьохрічні діти починають навчання в молодшій школі, яку називають підготовчим етапом. Лише в Англії та Уельсі зареєструватися у школу можна онлайн. Якщо ж дитину необхідно влаштувати в школу посередині навчального процесу, тоді слід звертатися до органів місцевої ради. Восени, за рік до початку навчання, розпочинається прийом документів дитини до навчального закладу в районі, в якому живе сім'я. Можна вказувати три бажаних школи, в порядку пріоритетності, проте обрати школу з іншого району теж дозволено. 15 січня - це дата закінчення реєстрації. Вже 16 квітня всі місцеві ради надсилають батькам відповіді щодо їхніх заявок. Якщо батьки вважають, що була порушена законність щодо зарахування, то до 15 травня вони можуть звернутися до судді зі справ шкіл і отримати рішення щодо цієї справи до 30 червня. Батьки 
дитини, які народились в проміжку між 1 квітня і 3 серпня, можуть просити про відтепер мінування на один рік, якщо вважають, що їх дитині зарано розпочинати навчання у школі. GCSE (General certificate of Secondary Education) - сертифікат про неповну середню освіту. Отримати сертифікат $\mathrm{GCSE}+$ обов'язковим завершальним етапом базової шкільної освіти Англії та Уельсу учнів 14 - 16 років, незалежно від типу школи державного чи приватного секторів.

В травні 2010 року, з приходом до влади консервативної партії на чолі з прем'єр-міністром Девідом Кемероном, Велика Британія відкриває двері сучасним тенденціям, що стосуються змінам узмісті системи загальної середньої освіти. “Освіта - це не тільки передача знань, але й наділення силою - силою моральною та духовною Освіта повинна передавати з покоління в покоління такі людські цінності, як справедливість, повага до всіх людей, почуття обов'язку в громаді, у суспільстві, турботу про ближнього, про культурну спадщину націй і людства" [3], - підкреслили автори реформи.

Напрямки своєї діяльності консерватори анонсували в урядовій програмі "Свобода, чесність, відповідальність”. Доречність реформ зумовлена бажанням підняти освіту на значно вищии? рівень конкурентності у світі. Нова влада висунула на розгляд такі освітянські питання:

- перегляд та зміну національного курикулуму;

- реформування освіти професійного напряму;

- перегляд і зміну екзаменаційної системи;

- реформування GCSE (General Certificate of Secondary Education);

- запровадження британської версії міжнародного ступеня бакалавра при отриманні GCSE;

- вдосконалення стеми діагностичного оцінювання [11].

Схвалення доречних напрямів роботи влади у ціи? галузі засвідчено у промові королеви Великобританіi? Єлизавети "Закон про освіту та дітеи?”, де наголошується те, що “... керуючись законом, учителі матимуть більше можливостеи? реалізувати навчальні програми у тому обсязі, які, на їхню думку, є необхідними для учнів та для досягнення ними високих освітніх стандартів" [10]. Серед головних завдань, які є основою нового закону про освіту і працюватимуть на успішну перспективу досягнення високих позитивних результатів, на думку королеви, стане подолання бюрократії та забезпечення доступного рівня освіти. Діючий міністр освіти Майкл Гав окреслив головні напрямки діяльності уряду в освітній галузі, назвавши програму реформ шкільної освіти “масштабною і жорсткою” [6]. Зокрема, він наголосив на тому, що реформа - це завжди нелегкий шлях побудови кращої системи в умовах обмеженого фінансування та подолання відставання країни за загальноосвітнім рівнем відповідно до світових показників; відходу від бюрократизму та повернення поваги й визнання компетентності учителів. Відповідно уряд повинен наполегливо працювати, пам'ятаючи, що головне завдання - це виховання наступної генерації [7]. На думку Майкла Гава, освітє завдання уряду полягає не у тому, щоб порівнювати існуючі досягнення освіти, а з'ясувати, як виглядає британська система освіти на фоні світових та загальноєвропейських стандартів, розробити план дії покращення освітніх напрямків враховуючі національні інтереси, оскільки в глобальному масштабі людство прогресує в усіх сферах, а, зокрема, освіті [6]. Зважаючи на світовий досвід, варто зазначити, що саме автономія шкіл, більш вимогливе зовнішне оцінювання та висококваліфіковані вчителі $є$ головними умовами, які забезпечують успіх реформ шкільної системи. Освітня політика уряду Великої Британії спрямована на зміну національного курикулуму на підставі вивчення та аналізу кращих світових зразків та визначення необхідного обсягу знань для учнів різних вікових груп. Курикулярна реформа за своєю значущістю розцінюється як національна проблема, а ії розв'язання спирається на демократичну платформу. Завдання загалом полягає у доповненні знань, формування компетентнісних передумов, зацікавлення учнів до навчання.

Згідно закону про освіту 2008 р., новий національний курикулум для початкової школи мав вступити в силу 3 вересня 2011 р. проте на засіданні 7 липня 2010 р. Кабінет Міністрів скасував рішення щодо цих змін, а саме: запровадження оновленої версії навчальних програм для першого і другого ключових етапів шкільної освіти. Консерватори планують надати школам більше автономії в тому, щоб реалізовувати навчальні програми, а також скоротити кількість методичних рекомендацій для вчителів. Такі наміри уряду вступають у суперечку з освітньою політикою консерваторів 1988 р., суть якої зводилася до скорочення повноважень регіональних відділків освіти (LEAs) і посилення централізованого управління освітою.

Новий навчальний курикулум британських шкіл передбачає скорочення виконання базових навчальних програм. Уряд прагне повернути національний план до його головної функції надати право вчителям реалізовувати навчальні 
програми на власний розсуд. У той же час планується залишити дієвим чинний навчальний план, оскільки поточні навчальні програми, затверджені 2000 р., досить гнучкі і передбачають надання школам і вчителям більше можливостей для маневру, проте залишили систему визначення рівня готовності учнів до навчання у старшій школі. Результат тестування учнів на 2-му ключовому етапі виступатиме надійним джерелом інформації для батьків у момент переходуїх дітей з початкової до середньої школи. Тестування $11+$ підсумовуватиме результати навчання у початковій школі та надасть можливість одержати офіційні показники індивідуальних досягнень школярів, а відтак і рівень викладання [5]. Обов'язковий компонент шкільної програми - надати вчителям свободу вибору навчального матеріалу. Великої уваги потребує початкова школа, де запровадження незалежного тестування навичок читання 6річних учнів дасть можливість підтвердити головну мету тестування - готовності учнів надалі вчитися й опанувати зміст шкільних предметів. Важливим є перехід в середню школу, де учні опановуватимуть вищий рівень знань, обгрунтований стандартами. У зв'язку з цим міністр освіти Майкл Гав, даючи інтерв'ю, заявив про необхідність повернення довіри до екзаменаційної системи а зокрема, зазначив він, що попередній уряд ігнорував його заяви i підтримував існуючий стан речей, що було в інтересах влади, і тим самим активно руйнував плани на отримання освіти сотень тисяч дітей щорічно. На його думку, створення “більш активної”, регулювальної системи академічних та професійних кваліфікацій, надання більших повноважень екзаменаційним радам у проведенні тестувань у більш жорстких умовах було “критичним для відновлення довіри до екзаменаційної системи” [8]. Запровадження британської версії GCSE для учнів з високими показниками успішності полягає у присвоєнні академічних кваліфікацій європейського зразка. Документи такого рівня нададуть молодим людям можливість конкурувати на світовому ринку праці. Міністр освіти Майкл Гав прокоментував ужиті урядом заходи так: “Наші молоді люди все більше змагатимуться за робочі місця та вищі навчальні заклади на глобальному рівні, і ми не можемо дозволити нашим учням складати іспити, що не відповідають світовим стандартам" [4]. В своїй промові у Вестмінстерській академії Лондона у вересні 2010 року заявив, що уряд готовий реформувати зміст середньої освіти, має намір впровадити ії як професійно зорієнтовану, яка б стала одним із головних напрямків освіти. Зокрема він зробив наголос на цінності професійних кваліфікацій та необхідності прирівняти за статусом професійно зорієнтовану освіту до академічної. Зі слів Майкла Гава можна підсумувати те, що професіи?но зорієнтована освіта має надавати учням можливості отримати професію або продовжити освітню підготовку, вступивши до коледжу чи університету [12].

Сьогодні за результатами іспитів спеціалізовані навчальні курси розглядаються як такі, що прирівнюються до академічних дисциплін. У сучасній Великій Британії спостерігається ріст інтересу школярів до вибору професіи?них курсів. За показниками 2008p., 540000 учнів обрали професійно зорієнтовані дисципліни для складання іспитів на отримання GCSE порівняно з 2007 р., коли цеи? показник становив 22 500. [9].

Висновки та перспективи подальшого розвитку у даному напрямку. Особливістю Закону про освіту 1994 року стало вдосконалення системи педагогічної підготовки вчителів, прийняття нових хартій батьків, які визначали та закріплювали їх права й обов'язки щодо дітей, школи та вчителів [3]. Отже, шкільна освіта Великої Британії в XX сторіччі пройшла низку етапів свого розвитку. Радикальне перетворення вона розпочала у XVII столітті. Англійська система освіти поєднує консервативний та ліберальний підхід до навчання. Погляди на освіту та виховання акцентувалися як на внутрішньому світі людини, так і на її здатностях до мислення та аналізу. Вона також поєднує різні погляди і принципи навчання. Ця система залишається однією 3 найкращих у світі.

Сучасний уряд Англії наполягає на впровадженні радикальних змін в освіті. Таке твердження мотивують передусім дієвістю

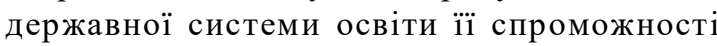
задовольнити потреби громадян. У програмі задіяні такі принципи: амбіційні стандарти, децентралізація відповідальності, високий рівень інформованості суспільства щодо результатів діяльності шкіл та чітко поставлені освітні цілі, звітність (передбачає інспектування), втручання у справи шкіл у напрямі, зворотному до рівня їх успішності (нагороди, допомоги) [1, 133 - 140]. Попри все, нині система освіти Великої Британії $€$ чи не найкращою у світі. Сьогодні на ії території діє 30000 державних шкіл і 2300 приватних (1 500 з яких - інтернати). Більшість державних шкіл (від 60 до 90\%) є змішані. Фінансування шкільної освіти здійснюється з держбюджету, школи одержують гранти від місцевої чи федеральної 


\section{ПОЛТТИКАУПРАВЛІННЯ ОСВІТОЮУКРАЇНИ ТА ВЕЛИКОЇ БРИТАНІЇ}

влади і ними розпоряджаються самостійно. Початкові школи мають теденцію об'єднуватися у так звані кластери для отримання статусу грантоуправителя. Сам розмір фінансування залежать від кількості учнів. Англійська система середньої освіти дійсно пройшла довгий і складний етап реформ впровадження різноманітних інноваційних нововведень. Важливим кроком вдосконалення став контроль осіти не лише на державному, але й на шкільному рівні (Шкільні управлінські ради). Позитивною $є$ своєрідна розмежованість навчальних вимог до учнів 3 різним рівнем успішності. Тож можна зазначити, що така політика уряду обречена на позитивні результати, про що й дискутують самі автори реформ, спираючись на певні соціологічні дослідження. Британський досвід впровадження освітніх реформ $є$ найбільш тривалим та суперечливим. Вивчення даного досвіду реформування середньої освіти Великої Британії $\epsilon$ доцільним і необхідним для вдосконалення вітчизняної системи середньої освіти $[1,133$ 140].

\section{ЛІТЕРАТУРА}

1. Лиценко I. О. Реформування середньоі освіти Великоі Британіі наприкінці XX - на початку ХХІ століття. Педагогічні науки. 2011. № 3 (13). C. $133-140$.

2. Про освіту: Закон України від 05.09.2017 p. № 2145-VIII. URL : http://zakon.rada.gov.ua/laws/ show/2145-19

3. Реформа шкільної освіти у Великобританії. URL: http://ocvita.in.ua/index.php? option=com content\&view $=$ article\&id=433:2010-01 - 16-17-58$\overline{2} 1$ \& catid $=32$ : languages $\&$ Itemid $=59$

4. DfE Michael Gove speech to Westminster Academy. Crown Copyright 2010. Available at: http:/ /www.education.gov.uk.

5. DfE National Curriculum.2010. Available at: http://www.education.gov.uk/curriculum.

6. Education Secretary Michael Gove outlines "formidable" school reforms. The Independent. September 6, 2010. Available at: http:// www.independent.co.uk/news/education.

7. Gove M. I've upset schools, reform isn't easy. Express.co.uk 11 July. 2010.Available at:http:// www.express.co.uk/posts/view/1862 .

8. Paton G. "Exams to be brought in line with world's toughest tests" Telegraph.co.uk 6 September. 2010. Available at: http://www.telegraph.co.uk/ education/educationnews/.

9. Paton G. "Government to overhaul vocational courses" Telegraph.co.uk 9 September.2010. Available at: http://www.telegraph.co.uk/education/.

10. Queen's Speech - Education and Children's Bill. Number10.gov.uk. 25 May 2010. Available at: http:/www.number10.gov.uk/queens-speech/.
11. The Coalition: our programme for government. Freedom, Fairness, Responsibility. Crown copyright. 2010. Available at: http://www.cabinetoffice.gov.uk.

12. Woodcock A. Gove to launch vocational education review. The Independent 9 September.2010. Available at: http:// www.independent.co.uk/news/education.

\section{REFERENCES}

1. Lytsenko, I. O. (2011).Reformuvannia serednoi osvity Velykoi Brytanii naprykintsi XX - na pochatku XXI stolittia [Reformation of secondary education in the UK at the end of the twentieth - early XXI century]. Pedagogical sciences. No 3 (13), pp. 133140. [in Ukrainian].

2. Pro osvitu: Zakon Ukrainy vid 05.09.2017 r. № 2145-VIII [On Education: Law of Ukraine dated September 5, 2017 No. 2145-VIII]. Available at: http:/ /zakon.rada.gov.ua/laws/show/2145-19[in Ukrainian].

3. Reforma shkilnoi osvity u Velykobrytanii [UK School Reform]. Available at: http://ocvita.in.ua/ index.php?option $=$ com content\&view $=$ article\&id $=433: 2010$ $01-16-17-58-21 \&$ catid $=32$ : languages $\&$ Itemid $=59[$ in Ukrainian].

4. DfE Michael Gove speech to Westminster Academy. Crown Copyright 2010. Available at: http:/ /www.education.gov.uk. [in English].

5. DfE National Curriculum. 2010. Available at: http://www.education.gov.uk/curriculum. [in English].

6. Education Secretary Michael Gove outlines "formidable" school reforms. The Independent. September 6, 2010. Available at: http:// www.independent.co.uk/news/education. [in English].

7. Gove M. I've upset schools, reform isn't easy. Express.co.uk 11 July. 2010.Available at: http:// www.express.co.uk/posts/view/1862. [in English].

8. Paton, G. (2010). "Exams to be brought in line with world's toughest tests" Telegraph.co.uk 6 September. Available at: http://www.telegraph.co.uk/ education/educationnews/. [in English].

9. Paton, G (2010). "Government to overhaul vocational courses" Telegraph.co.uk 9 September. 2010. Available at: http://www.telegraph.co.uk/ education/. [in English].

10. Queen's Speech - Education and Children's Bill. Number10.gov.uk. 25 May 2010. Available at: http://www.number10.gov.uk/queens-speech/. [in English].

11. The Coalition: our programme for government. Freedom, Fairness, Responsibility. Crown copyright. 2010. Available at: http://www.cabinetoffice.gov.uk. [in English].

12. Woodcock, A. Gove to launch vocational education review. The Independent 9 September.2010. Available at: http://www. independent.co.uk/news/education. [in English].

Стаття надійшла до редакції 12.06.2019 